\title{
Social Seducement: Towards the Foundations of a Pedagogical MODEL
}

\author{
Natalia Padilla-Zea ${ }^{1}$, Stefania Aceto ${ }^{2}$, Daniel Burgos ${ }^{3}$ \\ ${ }^{1}$ PhD in Informatics Engineering. Assistant professor. E-mail: natalia.padilla@unir.net \\ ${ }^{2}$ Graduate in Political Science. Senior researcher \\ ${ }^{3} \mathrm{PhD}$ in Informatic Engineering. Full professor \\ Universidad Internacional de la Rioja, Logroño, España
}

Received date: August 13, 2016 Accepted date: November 25, 2016

How to cite this article: N. Padilla-Zea, S. Aceto \& D. Burgos, "Social Seducement: Towards the Foundations of a Pedagogical Model", Ingeniería Solidaria, vol. 13, no. 21, pp. 45-52, January 2017. doi: http://dx.doi.org/10.16925/in.v13i21.1728

\begin{abstract}
Introduction: Social Seducement is a project intended to ease the re-entry of long-term unemployed people into society by involving them in the development of a social economy enterprise. This goal will be reached by giving them the opportunity to develop necessary skills via a serious game, in which they will learn the primary concepts, skills and attitudes for developing an enterprise successfully. This article was written in the year 2016 in the Universidad Internacional de la Rioja. Methodology: This paper focuses on the process necessary to develop a pedagogical model for this game and on explaining the foundations to be observed, i.e., the instructional model, the way the approach is related to the European Qualifications Framework and the specific competencies that a social entrepreneur must develop. Results: As a result of this study, we obtained a didactical basis on which to support the process of game-based learning. Conclusions: Our immediate focus is the development of each phase of the ADDIE (Analysis, Design, Development, Implementation, and Evaluation) model, developing external and internal material, placing content within the proper levels and testing the game in order to perform the piloting.
\end{abstract}

Keywords: gamification, pedagogical model, social economy, social seducement, team work. 


\section{SEDUCCIÓN SOCIAL: HACIA LOS FUNDAMENTOS DE UN MODELO PEDAGógICO}

Resumen. Introducción: seducción social es un proyecto que busca facilitar la reinserción en la sociedad de individuos que llevan un tiempo prolongado desempleados mediante su involucramiento en el desarrollo de un emprendimiento de economía social. Este objetivo se puede alcanzar al brindarles la oportunidad de desarrollar las habilidades necesarias a través de un juego serio, en el que aprendan los conceptos primarios, habilidades y actitudes para desarrollar una empresa de forma exitosa. Este artículo fue escrito en el 2016 en la Universidad Internacional de la Rioja. Metodología: el trabajo se centra en el proceso necesario para desarrollar un modelo pedagógico para este juego y en explicar los fundamentos que se deben tener en cuenta, es decir, el modelo instruccional, la forma en que el enfoque se relaciona con el Marco Europeo de Cualificaciones y las competencias específicas que un emprendedor social debe desarrollar. Resultados: como resultado de este estudio, obtuvimos una base didáctica para apoyar el proceso de aprendizaje basado en juegos. Conclusiones: nuestro enfoque inmediato es el desarrollo de cada fase del modelo ADDIE (análisis, diseño, desarrollo, implementación y evaluación), desarrollando material externo e interno, colocando contenidos dentro de los niveles adecuados y probando el juego para realizar el piloto.

Palabras clave: gamificación, modelo pedagógico, economía social, seducción social, trabajo en equipo.

\section{SEDUÇÃO SOCIAL: RUMO AOS FUNDAMENTOS DE UM MODELO PEDAGÓGICO}

Resumo. Introdução: sedução social é um projeto que procura facilitar a reinserção, na sociedade, de indivíduos que estão há um tempo prolongado desempregados mediante seu envolvimento no desenvolvimento de um empreendimento de economia social. Esse objetivo pode ser atingido ao oferecer-lhes a oportunidade de desenvolver as habilidades necessárias por meio de um jogo sério, no qual aprendam os conceitos primários, habilidades e atitudes para desenvolver uma empresa de forma bem-sucedida. Este artigo foi escrito em 2016 na Universidad Internacional de la Rioja. Metodologia: o trabalho se foca no processo necessário para desenvolver um modelo pedagógico para esse jogo e em explicar os fundamentos que devem ser considerados, isto é, o modelo instrucional, a forma na qual a abordagem se relaciona com o Referencial Europeu de Qualificações e as competências específicas que um empreendedor social deve desenvolver. Resultados: como resultado deste estudo, obtivemos uma base didática para apoiar o processo de aprendizagem baseado em jogos. Conclusões: nossa abordagem imediata é o desenvolvimento de cada fase do modelo addie (análise, desenho, desenvolvimento, implantação e avaliação), desenvolvendo material externo e interno, colocando conteúdos dentro dos níveis adequados e provando o jogo para realizar o piloto.

Palavras-chave: gamificação, modelo pedagógico, economía social, sedução social, trabalho em equipe. 


\section{Introduction}

The Erasmus+ project called Social Seducement aims to enhance social economy entrepreneurial skills of long-term unemployed people in order to ease their re-entry or re-inclusion into the labour market and society. To achieve this goal, activities and tasks proposed during the training are grounded on game-based learning theory.

Social economy, also known as the third sector, is a type of commercial activity whose first goal is not economic benefits for owners, but meeting social needs [1]. Thus, this type of enterprises intends to provide opportunities of local evolution by creating jobs in relation to local needs in such a way that both people and communities grow together, in this way meeting people's needs [2] cited by [1].

Though game-based learning has been under study for some time, more research is required. Arnab et al. [3] summarized several statements from different authors who explain that, "one of [the] biggest issues with educational games to date is the inadequate integration of educational and game design principles" and suggest that instructional expected outcomes need to be implemented within game mechanics in order to facilitate learning success.

Taking into consideration the capabilities of our target group and the features of social economy, the main contribution of this paper is that it studies different aspects involved in the establishment of the foundations needed for a proper pedagogical approach. The rest of the paper is organized as follows: first we review game-based learning experiences in the field of vocational and job-oriented learning. Afterwards, we study the European Framework of Qualifications. Next, we review the main compentecies addressed by the game as resulting from previous analysis. Finally, the last section outlines the main conclusions and further work.

\section{Serious Games in Vocational and Job-Oriented Training}

For this review, we selected a short but representative set of proposals intended to train vocational and job-oriented skills using serious games. Stuart [4] uses a blended learning approach to promote safety practices in furniture manufacturing. The main goal of this proposal is to reduce accidents in this sector by properly training students during their professional regulated instruction.

In this proposal, which is based on Kolb's model [5], the ADdIE (Analysis, Design, Development, Implementation, and Evaluation) model is used to design and develop the learning objects. Since the goal is to avoid personal damages, the author analyses the dangers associated with woodworking machines, which often provoke dangers, as well as the specific learning goals regarding these two aspects. The content of the learning objects (LO) are specified based on educational goals and a storyboard, paying special attention to feedback offered to students. Later, learning material is generated using proper tools that allow the creation of interactive content and quizzes. Furthermore, additional text is produced in order to explain multimedia content. Finally, the Lo are tested in order to determine if there are any technical or functional problems.

Next, this design was developed within a blended learning space, where students received practical demonstrations from a lecturer over a period of twelve weeks. Following on, they experienced a period of virtual learning, during which they used the Lo to learn about safety concerning woodworking and participated in forums, discussing and sharing experiences with other students. Finally, students provided feedback about the experience and their comments helped improve the proposal.

In concluding this experience, the author explains that the virtual environment allows students to learn what and how to function in the practical lab, and provides advice about safety practices. Additionally, lab practices allow students to realize how not respecting theoretical instructions can provoke real accidents and cause injury to themselves.

Related to the above experience, but more within the scope of Social Seducement, we find the experience of Weber and Funke [6], which specifically focuses on entrepreneurship. This proposal was developed using the "curriculum-instruction-assessment" triad mentioned in [6]. The first step centers in the definition of particular curricular goals. The second step involves the selection and develpoment of suitable material that will allow students to achieve the previously stated goals. The final step entails conducting an evaluation.

In order to define curricular goals, authors developed a list of challenges that entrepreneurs 
usually face and the competencies they must acquire. As a consequence of this study, four goals were stated: 1) in the knowledge domain, students have to obtain proper mental models for calculating financial budgets, strategies of networking, techniques for moderating teamwork and criteria for good presentations; 2) in the field of behaviour, they must improve skills for conducting purposeful and quick information retrieval in databases, for employing decision-making strategies and tools in order to set up a solid financial plan, for networking, for adequately dealing with team conflicts, for taking down the minutes of team meetings and for developing convincing and sound arguments, as well as impressive presentations; 3) related to personal attitudes, it is expected from them to make progress in conscientiousness, patience, achievements, orientation, etc.; and 4) in relation to social construction ideology, they have to develop values and activities to better understand the past and present in order to improve the future of society.

In the second step, the authors stated a set of six instructional activities that occurred iteratively during the course: 1) an initial session is given to introduce the instructional programme in which every actor involved views a video oriented towards promoting motivation; 2) groups of fourto-six students create a business plan for real startups during a semester in which they are in contact with the Chamber of Industry and Commerce; 3) students attend lectures about products and services, market and competition, sales and marketing, business models, organization and financial planning; 4) students are given weekly supervised tutorials to practice what they have learned; 5) e-learning multimedia modules are offered for individual students, developed on the basis of the 4C/ID approach; 6) students present results to a jury and attend a closing ceremony.

Finally, an evaluation of the process was conducted. During this process, the authors assessed the usefulness of the initial video, the problem-based approach (building a business plan), lectures, tutorials and individual e-learning. They obtained good results in almost every aspect, but found that technical problems were reported as a negative factor.

In [7], we find a game-based blended learning experience involving mechanics mechatronics. This game is played during 400 hours over a period of two years, the timeframe for the curriculum of the course. The game design aims to replace a significant part of the theoretical and traditional classroom-based content. The student will play a part of the game with a specific training goal and after completing it successfully, will practice it in the workshop.

To design this game, the authors followed the 4C/ID approach: in the first phase, they focused on what the student has to do and how it can be divided into singular tasks; next, supportive and procedural information for routine actions from an expert system were combined in order to provide just-in-time and proper information. Finally, the game mixes simple and more complex tasks via a nested structure that enables students to move between different difficulty levels.

The authors employed a simulation and sandbox approach in which the main scenario is a machine hall. The machines that students will use in the workshop are represented in the machine hall. To maintain the flow of the game, rewards are linked to successful achievements that are closely related to the way in which students have to work in the real machine. Of course, these rewards are coupled to direct learning results, but also to teachers' perception while students play and how they relate to one another.

The game was developed and called Kenteq Craft [8]. After its application with 100 students, results reflected that the game improves motivation and promotes social learning both in and outside of the game. In addition, students believed that the game was well designed, immersive and eased the process of linking learning in the game with additional learning material.

Related to safety at work and building learning, O'Rourke [9] proposes the White Card Game, which intends to promote safety in the carpentry environment. The pedagogical model of this game is based on recreating real-world situations in order for students to become acquainted with decision-making within work circumstances and when experiencing problems. To achieve this goal, the authors contacted industry experts who participated in the game design process; teachers with safety training expertise also participated in these meetings. In this way, the learning design team combined industry and pedagogical views whose components proposed and assessed training materials and offered suggestions about scenarios that have been correctly designed to obtain proper 
competencies. In addition, the game includes facilities for engaging students, such as tutorials and catering to novice students or those who presented some problem related to, for example, the English language, or who possessed low gaming expertise.

This is a first-person shooter game that takes place on a multi-storey construction work site. The player is a new employee who has to identify hazards and report them to their supervisor. This supervisor acts as a facilitator by giving the player some guidance during the game. While playing, students are provided with learning content and have to try to overcome several challenges based on this information. The game allows students to improve their knowledge by giving them several attempts of finding the successful solution.

This game was presented over a period of one hour in which students aged 16 to 19 were able to make several attempts at completing it successfully. In this session, collaborative problem-solving skills were promoted by allowing students to ask questions both to the teacher and to other students. Students expressed they had fun and that they had learned the content of the game easily. Moreover, they indicated that the learning experience was richer than using traditional methods and they stayed after class to continue playing and trying to improve their scores.

Other approximations can be found in the work of Belloti et al. [10], who performed a wide scope analysis about various serious games and their use as part of a blended learning strategy to teach entrepreneurial skills. This strategy is intended to include specific serious games during a period of learning in order to practice and reinforce knowledge and skills. The strategy is flexible, since it has been applied both in a complete course and as part of a module.

In the first case, teachers presented business topics in short and these explanations were completed by inviting entrepreneurs to deliver a range of talks. Games were played at home as homework and for promoting competition between students. The scheduled session was preceded and followed by debriefings. In addition, reports and questionnaires were completed by students at home. Finally, a ranking was performed based on grades achieved during the course. The ranking was used to decide the starting position in a final competition. To summarize the study, authors elaborated on the games they subsequently used and how these contributed to learning.

To conclude this study, the authors highlighted that including games in the learning process increased the motivation of teenage students, but that more serious games can also be utilized for older students. This is possible due to the different level of knowledge that must be learned and because the initial level of students may vary. Thus, although the authors admit that engagement was not very high, this initiative was well received by students.

\section{The European Qualification Framework (EQF)}

The European Parliament and the Council of the European Union establishes a framework for linking the qualifications of different countries in the European Union. It is a translation intended to ease an understanding of the different national qualifications in order for students and workers' qualifications to be comparable in different countries based on common regulation. This $\mathrm{EQF}$ covers from basic compulsory education (Level 1) to Doctorate (Level 8) and is "focused on the outcome of learning and the person's actual knowledge and skills rather than the amount of study needed to complete the qualification programme" [11]. This approach is based on three main elements:

- Knowledge: described as theoretical or factual

- Skills: described as cognitive (involving the use of logical, intuitive and creative thinking) and practical (involving manual dexterity and the use of methods, materials, tools and instruments)

- Competence: described in terms of responsibility and autonomy

The pedagogical approach we aim to develop for the game needs to be compliant with the EQF and articulated in a way that it ensures that players develop the knowledge, skills and attitudes necessary to be able to effectively manage a social enterprise. 


\section{Competencies in Social Seducement}

Social economy enterprises have a set of features that differentiate them from other types of enterprises. For this reason, in addition to capabilities for developing a business plan or conducting management, social entrepreneurs need a set of complementary skills to succeed. However, there is no standard portfolio to define what competencies a social entrepreneur should have.

In order to determine the complete set of competencies for this type of entrepreneurs, as part of the SocialSeducement project, a competencies framework was developed. To obtain this portfolio, a wide survey was performed, including different actors involved in social economies in Italy, the United Kingdom, France, Belgium, Spain and the Scandinavian countries. Results were also triangulated with the previous experience of project partners and a literature review. This portfolio is extremely complete and falls outside the scope of this paper. Nonetheless, we can summarize its findings as a set of competence packages, thereby presenting its global vision:

- Understanding the concept of social economy: social economy enterprises have several features that differentiate them from a traditional enterprise such as type of governance, use of benefits, rules and regulations related to tax, etc. For this reason, game players need to learn these principles in order to execute the idea behind this game properly.

- Conception of the idea by a group of persons: since the game is played in groups, players need to develop skills in order to work collaboratively and to conceive and develop their business idea. In this package, we will train empathy, capacity for listening, mediation capabilities, etc.

- Establishing a business plan: to create a proper business plan, several competencies need to be trained, such as research and analytical capabilities, development of a market study and using financial instruments. Additionally, editorial skills are needed to write out the business plan and present the idea and proposals to stakeholders. It is also crucial for players to be capable of learning from previous experiences and adapt the business plan to changes in the local environment.

- Management, including communication and marketing: in this package we include skills related to bookkeeping, the legal environment, administrative requirements, etc. Students will also need to be able to organize meetings, execute planning, make decisions, use Information and Communication Technologies (ICT) instruments, etc.

- Creation of a conductive stakeholder environment: rootedness in the local environment is key in social economy enterprises, as are direct contact with local authorities, other social economy or traditional enterprises, universities, citizens, etc. These relations allow entrepreneurs to discover local needs, define and develop proper activities to solve these needs and evolve alongside local development.

- Evaluation and impact assessment: social economy enterprises also need to evaluate their activities, revise strategies based on the results obtained and attract new investors according to the impact achieved.

- Operations: beyond the idea's development or the planning strategies to be implemented within the local environment, a social economy enterprise needs to be managed on a daily basis. For example, deliveries to customers, meetings with local actors, negotiations with banks, etc., that need to be maintained and studied in order to properly assess the implications of these actions and how they will help (or hinder) the business.

\section{Towards a Comprenhensive Pedagogical Model for Social Seducement}

In previous sections, we studied different approximations of serious games, as well as the $\mathrm{EQF}$ and the concrete set of competencies that players of Social Seducement have to develop by playing the game. From these studies, we have learned some lessons, which we outline in this section.

In the second section, the experiences reviewed gave users the opportunity to address problems that may arise in real situations. By doing so, they can test their ideas, knowledge and skills in order to check their validity and in this way learn without incurring in the risks associated with a real situation. In addition, important statements were proposed related to the usefulness of having a facilitator assist in the process of learning 
and including experts and real situations in content development.

In order to perform the instructional design (ID) of a course, a subject or a game, several models exist that can be followed, as noted in the experiences included in section 2. Moreover, as stated in [4], "the pedagogical approaches used in student's education can vary greatly depending on the nature of the learning required". The ADDIE model [12-13] is considered to be the basis on which all other models are constructed. Thus, we have found that the ADDIE instructional design model (IDM) fits the needs of Social Seducement, as it is a widely employed IDM that supports many other models. The phases of this IDM are explained below, as well as the way in which they will be implemented in Social Seducement:

1. Analysis: in which the scenario has to be defined (students and their characteristics, context of use, available resources, etc.). For this first activity, a wide range of key actors in social economy entrepreneurship were engaged in the survey in order to better understand the needs associated with the creation of a social enterprise. In addition, results obtained from the survey were triangulated with a literature review in order to adjust conclusions.

2. Design: tasks to be performed in this phase are related to learning itself. The teacher or instructor has to describe the goals, design how they will be assessed, choose an approach for providing students with materials; define the general didactic model, plan instruction by deciding elements and order related to the content, design activities for students and identify the resources they will need. In Social Seducement, the different concepts to be learned will be structured and translated into levels and sub-levels, and will be related to storytelling, which will drive the learning process itself.

3. Development: this phase is intended to generate the educational content designed in the previous phases. In Social Seducement, we will also take into account the need for making links to real situations. Thus, we will include two types of materials: internal and external. The internal material will consist of real stories of success or failure in the creation and management of social economy enterprises. External material will comprise didactic documents, videos, etc., retrieved from existing sources on the Internet and/or by accessing relevant publications and/ or the information databases of relevant actors.

4. Implementation: in which instruction takes place. In this phase, the instructor has to support students to understand content, encourage their learning and follow up on their progress. In Social Seducement, this phase will be developed by a pilot experience in five countries (Italy, Spain, Belgium, Sweden and the uK) during late 2016 and early 2017, where 36 users of the focus group (long-term unemployed people) in each country will play the game.

5. Evaluation: according to the potential for applying this model, both iteratively and sequentially, evaluation can be either formative or summative. In Social Seducement, from the piloting explained in phase 4 , we will obtain a preliminary set of results about learning and the game that will allow us to start a new iteration of the process in order to refine and validate the game.

On the other hand, taking into consideration the fact that Social Seducement will be played in several countries within the European Union, the programme-level learning outcome assessment will work on the three defined levels of knowledge (to know...), skills (to be able to...) and competencies (to behave with...). In particular:

- Skills assessment (performed at individual level) will occur: 1) through self-evaluation by learners at the beginning and at the end of the game. An online questionnaire is being drafted, which players will have to complete at the beginning and at the end of the game in order to gain awareness of their self-perception and progress as a result of playing the game. The facilitator will play a key role in supporting comparisons for each player between their initial and final set of skills; 2) through automatic tests while the game is being played.

- Competencies (behaviour) assessment will be mainly provided by the facilitator (both at individual and at group level) based on a set of gamification measures currently being designed.

- Knowledge assessment performed alongside the game will be structured around several types of quizzes to be solved individually or in groups, in order to promote both individual commitment, learning by doing and collaborative learning. The accuracy of solutions will be checked automatically. 


\section{Conclusions}

In this paper we presented the Social Seducement project, which is intended to promote social economy entrepreneurial skills in long-term unemployed people. In addition, we have reviewed a set of experiences related to the main aspects of this project, i.e., serious games and job-oriented learning in a bid to obtain a proper approach for developing the pedagogical model. We also presented the EQF, which will guide the assessment process and enable a comparison of competencies obtained within a European framework. Afterwards, we described the main set of competencies in which we aim to train participants, obtained from the performed survey, as well as the previous experience of partners and a literature review.

As a result of these studies, we have obtained the main features of our pedagogical model, which can be summarized as three primary foundations: the ADDIE IDM, assessment based on knowledge, skills and behaviour; and the seven competencies package created.

Our immediate focus will be the development of each phase of the ADDIE model, developing external and internal material, placing content within the proper levels and testing the game in order to perform the piloting.

\section{Acknowledgements}

This work is supported by the project Social Seducement (Contract number: 2014-1-UKO1-KA200-001830 3013-4197), funded by the European Commission under the Erasmus+ Programme, and UNIR Research (http://research.unir.net) at Universidad Internacional de La Rioja (UNIR).

\section{References}

[1] A. Amin, A. Cameron \& R. Hudson. Placing the Social Economy. New York, USA: Routledge, 2003, p. 1.
[2] A. Molloy, C. McFeely \& E. Connolly. Building a social economy for the new millennium. Derry: Guildhall Press/NICDA 8, 1999.

[3] S. Arnab et al., "Mapping learning and game mechanics for serious game analysis", British Journal of Educational Technology, vol. 46, no. 2, pp. 391-411, 2015.

[4] A. Stuart, "A blended learning approach to safety training: Student experiences of safe work practices and safety culture", Safety Science, vol. 62, pp. 409-417, 2014.

[5] L. Sugaarman. "Kolb's Model of Experiential Learning: Touchstone for Trainers, Students, Counselors, and Clients", Journal of Counseling \& Development, vol. 64, no. 4, pp. 264-268, 1985.

[6] S. Weber \& S. Funke, "A research and evidence-based entrepreneurship educational education program at Ludwig-Maximilians University (LMU), Munich", in Becoming an entrepreneur, S. Weber, F. Oser, F. Achtenhagen, M. Fretschner \& S. Trost, Eds. Rotterdam: Sense Publishers, 2014, pp. 177-195.

[7] H. Lukosch, R. van Bussel \& S. A. Meijer. "A serious game design combining simulation and sandbox approaches", LNCS, vol. 8264, pp. 52-59, 2013.

[8] H. Lukosch, R. van Bussel \& S. A. Meijer. "A game design method for learning built on hierarchically structured components", Proceedings of ICERI2012, 5th International Conference of Education, Research and Innovation, Madrid, Spain, Nov. 19-21, 2012, pp. 4586-4591.

[9] M. O'Rourke, "Increasing engagement with vocational education and training: a case study of computer games-based safety training", in 2013 postgraduate research papers: a compendium. Adelaide, Australia: National Centre for vocational education research, 2014, pp. 113-133.

[10] F. Belloti et al., "Serious games and the development of an entrepreneurial mindset in higher education engineering students", Entertainment Computing, vol. 5, pp. 357-366, 2014.

[11] European Qualification Framework, EQF, Available: http://www.accreditedqualifications.org.uk/european-qualifications-framework-eqf.html

[12] C. Belloch, "Diseño instruccional", Unidad de Tecnología Educativa de la Universidad de Valencia, Spain. Available: http://www.uv.es/bellochc/pedagogia/EVA4.pdf

[13] P. C. Muñoz Carril, "Modelos de diseño instruccional utilizados en ambientes teleformativos", Revista Digital de Investigación Educativa, vol. 2, pp. 29-59, 2011. 